\title{
The Changing Role of CEOs in Dutch Listed Companies, 1957-2007
}

\author{
KEETIE SLUYTERMAN \\ GERARDA WESTERHUIS
}

This paper looks at the position of CEOs in Dutch listed companies in the context of institutional change. Following up on discussions on Varieties of Capitalism and the contrasts between coordinated and liberal market economies, we explore the position of the CEO in the Netherlands in the second half of the twentieth century. On the basis of our database of Dutch CEOs, as well as an analysis of articles and published interviews, we show that the move toward a more liberal market economy had a clear impact on the position of CEOs and on the way their role was perceived. This paper highlights the importance of studying leaders in their historical context, with

() The Author(s), 2021. Published by Cambridge University Press on behalf of the Business History Conference. All rights reserved. This is an Open Access article, distributed under the terms of the Creative Commons AttributionNonCommercial-NoDerivatives licence (http://creativecommons.org/licenses/ by-nc-nd/4.0/), which permits non-commercial re-use, distribution, and reproduction in any medium, provided the original work is unaltered and is properly cited. The written permission of Cambridge University Press must be obtained for commercial reuse or in order to create a derivative work.

doi:10.1017/eso.2020.77

Published online March 12, 2021

KeEtie Sluyterman is emeritus professor of business history at the Department of History and Art History of Utrecht University. She has written or jointly authored business histories of Royal Dutch Shell, Heineken and many others. Her research interests include multinationals, Corporate Social Responsibilities and Varieties of Capitalism with a focus on the nineteenth and twentieth centuries. Contact information: Utrecht University, Department of History and Art History, Drift 6, 3512 BS, Utrecht Netherlands. E-mail: k.e.sluyterman@uu.nl.

GERARDA WESTERHUIS was assistent professor at Utrecht University. Her research interests include corporate governance and financing. She was also Board Member and member of the Admissions Committee of the new BA-program in Philosophy, Politics \& Economics (PPE). Currently, she works as a senior sector economist at ABN AMRO Bank. Contact information: Utrecht University, Utrecht Netherlands. E-mail: g.k.westerhuis@uu.nl.

We would like to thank Bram Bouwens, Jan Luiten van Zanden, and three anonymous reviewers from Enterprise \& Society for their stimulating comments on earlier drafts. We are grateful to Winny Bierman for her initial work on the database on which this paper is based. 
implications for the selection of future CEOs as they face increasing pressure on issues such as inequality and climate change.

Keywords: Varieties of Capitalism; Corporate governance; The Netherlands; CEOs

\section{Introduction}

Capitalism is under pressure. In the 1990s and 2000s, sociologists and political economists discussed the many varieties of capitalism and argued that different forms of capitalism could be equally successful in their own way, and there was no need to converge to one system. In this debate, capitalism is considered as a set of national institutions that can have different forms and shapes in different countries. The debate started with contrasting capitalism in the United States and Germany. It evolved into a more abstract comparison between a liberal market economy (LME) and a coordinated market economy (CME) with the seminal article by Peter Hall and David Soskice in 1999, who also introduced the idea that institutional complementarities give endurance to a certain set of institutions. The varieties of capitalism debate ended in comparing many variations, including Mediterranean, Eastern European and Asian models. ${ }^{1}$ What they implied with their emphasis on variety is that there was no need for European (or other) countries to follow the dominant neoliberalism of the United States to be economically successful. However, from the 1990s onward, many European countries did move distinctly in a more liberal direction, and that process is at present heavily contested. The public demands a more sustainable and more equitable capitalism, and that means other types of pressures on companies and their leaders. In this paper, we use the framework of varieties of capitalism not so much to compare countries but much more to trace changes over time with a focus on the Netherlands and the position of the CEO.

In May 2002, after the dot-com bubble had broken, The Economist wrote: "Business leaders are being knocked off their pedestals faster than Communist heroes after the fall of the Berlin Wall." However, how had those business leaders come to be placed on their pedestal in the first place? And why were they suddenly turned from heroes into hate figures? Can we expect a new type of leader to rise to the top? To pave the way for finding answers to these questions, we go back in time and explore the question of how changing institutions and perceptions influenced the role of the CEOs of Dutch listed companies during the period 1957-2007.

1. Hall and Soskice, Varieties of Capitalism; Crouch, Capitalist Diversity and Change; Hancké, Rhodes, and Thatcher, Beyond Varieties of Capitalism; Morgan, Whitley, and Moen, Changing Capitalisms?; Whitley, Divergent Capitalisms. 
The Netherlands is an interesting case because the country had a liberal market economy at the start of the twentieth century but gradually moved toward a coordinated market economy from World War One onward, and back again to a more liberal market economy since the 1980s, though the extent to which the country became a liberal market economy is still under review. ${ }^{2}$ The study of the position of the CEO in the company can shed more light on those changes.

We use a mixed method approach in which we combine statistical data on Dutch CEOs between 1957 and 2007 to show changes in their characteristics over time, with more qualitative information on how the CEOs and the media perceived this role. In this way we provide more context and meaning to our empirical findings.

We will first discuss some international literature on the role of the CEO in its historical context. Then we explain our approach and present our database of the chairmen of the executive boards of Dutch listed companies over the period 1957-2007 and discuss our findings. Finally, we show how the position of the leader of the company was perceived in the Netherlands in the 1950s and 1960s versus the 1990s and 2000s. We build a picture on the basis of published interviews with company executives and add some general observations from contemporary literature.

\section{Historical Debates about the CEO}

CEOs have been the object of historical research for many years. Initially, researchers focused on the societal background of the CEOs because they were interested in social mobility. They wanted to know whether the leaders of listed companies came from more diverse backgrounds because, in theory, the division of ownership and management in listed companies made it possible for people without capital to reach the top on merit only. In various U.S. studies, the "from rags to riches" myth was debunked. ${ }^{3}$ A Dutch study by Vinke concluded, on the basis of a 1950 database, that the CEOs of listed companies came from the higher ranks of society. If anything, the social mobility among leaders of family firms was somewhat higher than those of listed companies. ${ }^{4}$

These studies formed part of a general interest in elites in societies. CEOs and, more broadly speaking, the corporate elite is seen as an important part of the elite, though small in actual numbers. The elite is often referred to as holders of positions of command. In that sense, elites are studied "as superior social groupings reflecting a particular class or social status."

2. Sluyterman, Varieties of Capitalism; Touwen, Coordination in Transition.

3. Friedman and Tedlow, "Statistical Portraits."

4. Vinke, Maatschappelijke plaats.

5. Maclean, Harvey, and Chia, "Dominant Corporate Agents." 
In the 1980s, elite research received new impetus through the work of Pierre Bourdieu, who was interested in the elites' basis of power and the reproduction of their power. In 1978 Bourdieu and Monique de Saint Martin published a study in which they analyzed the presidents of France's largest industrial and commercial firms, banks, and insurance companies. They concluded that there were different routes to the top: one based on the family business but another based on the right education. ${ }^{6}$ Subsequently, Bourdieu underlined the importance of different forms of capital, including economic, cultural, social, and symbolic capital, as the ultimate source of power in society.

Bourdieu's theories led to numerous studies on the rise and membership of people to the elite. In case of the corporate elite, these studies more specifically focus on the rise of persons to positions at the corporate board level. A Dutch study from the 1980s compared the accession to the CEO position in the Netherlands with the findings of Bourdieu and de Saint Martin. The author, Beekenkamp, found more social mobility and a less dominant role of education in the Netherlands compared to France and argued for inclusion of the experiences acquired during career paths as one of the factors in reaching the top. ${ }^{7}$ Comparing the situation in 1995 with the 1970/1972 period, Hartmann concludes that the rise to the position of chairman in France was indeed still largely dependent on education, while in Germany social origin was the route to chairman positions. ${ }^{8}$ Another study, focusing on Danish CEOs, also reduces the role of elite universities and instead emphasizes experiences in the economic field. ${ }^{9}$ However, the ascension to board level positions does not automatically ensure accession to membership of the most powerful elite, according to Maclean, Harvey, and Chia. In their comparison of the power elite in France and Britain, they show how accession to the field of power depends on interaction with other dominant agents within broader social networks. Therefore, they studied the relationships and linkages of company directors, not just between corporations but also with other public, private, and charity organizations in cultural, educational, and governmental networks. That led them to conclude that "belonging to boards is an important element in building and participating in networks, but does not on its own predetermine accession to the field of power." ${ }^{10}$ For that reason, Hjelbrekke et al. examined the Norwegian field of power in 2000 by focusing on public, private, military,

6. Bourdieu and de Saint Martin, "Le Patronat."

7. Beekenkamp, President-directeuren, posities en patronen. See also Dronkers, "Mythen over Elites."

8. Hartman, "Class-Specific Habitus."

9. Ellersgaard, Larsen, and Munk, "A Very Economic Elite."

10. Maclean, Harvey, and Chia, "Dominant Corporate Agents." 
educational, cultural, and judicial institutions, allowing them to incorporate the whole social network. Thus, their work analyzes different types of capital that separate the different fractions in the field of power and identifies which of them are most open for social mobility. ${ }^{11}$

The last two articles bring us to the theme of social networks, which is closely related to the investigation of corporate networks and corporate power. Corporate networks are formed by board interlocks: ties between firms created by directors having more than one board position. In the 1970s, the first Dutch corporate network studies appeared, inspired by international examples. ${ }^{12}$ The collections of data were subsequently used for later studies, including Heemskerk's Decline of the Corporate Community. ${ }^{13}$ In 2014, the edited volume by David and Westerhuis compared the development of corporate networks in different countries around the world during the twentieth century. In the Netherlands, the overall corporate network followed a path of increase (until 1928), temporarily decline (in the 1930s), consolidation (1950s-1960s), and very gradual decline (since 1970s). ${ }^{14}$ In fact, the Dutch corporate network did not decline significantly until the turn of the century. ${ }^{15}$ Sometimes these studies also include relations and linkages to politics. Often these studies describe the density of the network, across time or across countries, assuming that a denser network relates to more powerful directors. However, it is hard to "prove" what the actual power and influence of these directors are. So, in another article on Dutch directors and networks, Jong, Fliers, and Westerhuis focus on the effects of individual directors on corporate strategies and firm performance. They identified a number of individuals who are related to corporate strategies and performance. Biographies and other archival materials provide explanations for their systematic relation with corporate outcome variables such as performance, debt, and investments. ${ }^{16}$

Above mentioned streams of research have in common that they focus on the corporate elite and its possible power to set agendas in corporations, political parties, and government. Although these are important issues, they are not the subject of our paper. This paper examines how the role of the CEOs within their companies evolved over time and how this role was perceived by CEOs themselves and by the media. This focus relates to broader developments in corporate governance, and how changing institutions and perceptions influenced the role of the CEOs.

11. Hjelbrekke et al., "Norwegian Field of Power."

12. Dronkers and Stokman, Nederlandse elites in beeld; Stokman, Wasseur, and Elsas, "The Dutch Network."

13. Heemskerk, Decline of the Corporate Community.

14. David and Westerhuis, Power of Corporate Networks.

15. Westerhuis, "Dutch Corporate Network."

16. Jong, Fliers, and Westerhuis, "Exceptional Big Linkers." 
We take the varieties of capitalism debate as starting point but focus on changes over time. In order to trace changes over time, we assume that there are two CEO models, two stereotypes that are typical of, respectively, the coordinated market economy (CME) and the liberal market economy (LME). Judging from the literature, we expect the CEOs in a CME to be chairpersons of the executive board who are considered "first among equals." They have followed a career in the company that they are leading, have a business-related educational background, and know the business inside out. They are loyal to the company and share its values. Their main task is to coordinate internal processes, and their purpose is to assure the continued growth of the company to the benefit of all those involved, especially the employees. They stay in the CEO position until retirement. In contrast, we expect the CEOs in an LME to be brought in from outside and considered individually responsible for the performance of the company. They are no longer expected to possess specific knowledge of the industry the company is involved in. Instead, they have more general knowledge of management and finance. Their main task is to formulate a new strategy for the company and convince external parties of the merit of that strategy. Their goal is to increase shareholder value. Because external CEOs are not yet familiar with the company, it is not expected that they should feel specific loyalty to it, so their loyalty has to be bought by incentives such as bonuses and share options. If their performance is disappointing, they are dismissed. ${ }^{17}$ The CME and LME models give us a framework to distinguish between different types of capitalistic economies in time and space. The distinction between managerial and investor capitalism, as we will see below, relates to these broader CME and LME dichotomies but has the firm as its central focus and not the economy as a whole. It pictures the dominant actor within firms and shows a change from management to shareholder dominance over time.

In the varieties of capitalism debate, Germany is seen as a typical CME country and the United States as the typical LME country. However, if we look at developments in the United States, we also see changes over time - what in fact seems like a shift from the CME to the LME model. In a metastudy about American business elites, Walter Friedman and Richard Tedlow showed how the way business elites were portrayed shifted over time. In the context of our paper, it is interesting to note that in the 1950s the professionalization of business executives was underlined. After the notorious robber barons and impressive self-made men, came the professional executives, who were more like "grey bureaucrats." 18

17. The models are based on the literature in footnotes 1 and 2 as well as in Shiller, Finance and the Good Society, ch. 1, "Chief Executive Officers," 19-26.

18. Friedman and Tedlow, "Statistical Portraits," 89-113. 
They were not just bureaucrats but executives of the largest companies and supposed to act as "corporate statesmen," whose task it was to maintain a fair balance between the interests of various groups of stakeholders, including shareholders, employees, customers, and the public at large. ${ }^{19}$ Apparently, in the 1950s the American CEO had some characteristics that were aligned with our CME model of CEO.

In his study on different types of corporate control over time, Neil Fligstein argued that in the interwar years the focus of the typical U.S. executive changed from a focus on manufacturing to a focus on sales and marketing, and this shift was reflected in the educational background of executives. Fligstein uses the term "president" to refer to the person who was the executive in charge. Whereas in 1929 a background in manufacturing was, with 36 percent, the most usual among presidents (or CEOs), in 1959, those with a background in manufacturing were down to 30 percent while those with a background in sales accounted for 24 percent. However, the development did not stop there. The strategy of diversification led to presidents who predominantly took care of the finances. By 1979 those with an accounting background had become the largest group of presidents (31 percent), and presidents with a manufacturing background had dropped to 22 percent. ${ }^{20}$ This focus on financing continued into the 1990s but in a different way because the creation of shareholder value, not diversification, became the main preoccupation. ${ }^{21}$ Fligstein paints a picture of U.S. business leaders that suggests a shift from the CME to the LME model.

Though phrased differently, William Lazonick and Mary O’Sullivan also highlighted a shift in the position of CEOs in relation to the rise of the shareholder value ideology in the United States. The interests of the CEOs became tied to those of the shareholders via remuneration structures, including stock options. As a consequence, U.S. companies and their CEOs shifted their strategies from retaining profits and reinvesting them again to a strategy of downsizing their labor forces and distributing profits to their shareholders. ${ }^{22}$

Rakesh Khurana interpreted the developments in the United States in a similar way, as a transition (beginning in the 1980s) from a system of managerial capitalism to a system of investor capitalism that led to a fundamental change in the perception of CEOs and their role. In addition, he argued that this shift in the relationship between owners and managers in American capitalism, together "with a new quasi-religious conception

19. Reich, Supercapitalism, 45-46.

20. Fligstein, Transformation of Corporate Control, 14-16, 280-286.

21. Fligstein, Architecture of Markets, 168-169.

22. Lazonick and O’Sullivan, "Maximizing Shareholder Value." 
of business, an historic expansion of the number of Americans investing in the stock market, and the resulting emergence of the contemporary business press," led to the figure of the "charismatic CEO," the "saviour of the company," hired from outside through an irrational and flawed search process. ${ }^{23} \mathrm{He}$ did not see this as a positive development. Sketching a similar picture of the changing role of corporate CEOs in the United States, Mark Mizruchi and Linroy Marshall highlighted the paradoxical situation that, while CEOs compensation increased rapidly since the 1980s, CEOs autonomy declined. They see this development as worrisome because it tends to encourage CEOs to focus on short-term policies and narrowly formulated company interests. ${ }^{24}$

The various U.S. studies all point toward the selection of different types of CEOs in different time periods, and some raise concerns about recent developments. How did Europe compare to the United States? The first problem with discussing Europe is the wide variation between countries despite European economic integration. In 1999 Michael Mayer and Richard Whittington compared the top British, French, and German managers in 1983 and 1993 to see whether the managerial elites had become more similar over the past ten years. They found far fewer changes than they had expected:

German top managers stayed loyal to their technical traditions and were often members of owning families. In France, both state and family connections were still important, and engineering training provided a common starting point. British managers, on the other hand, were overwhelmingly professional managers independent of state or family, typically having strong financial backgrounds. ${ }^{25}$

Mayer and Whittington concluded that 1993 was perhaps too early to see significant convergence in Europe, supposedly toward a more shareholder oriented CEO.

A similar question was posed by Wouter Fioole, Hugo van Driel, and Peter van Baalen with regard to the background of German and Dutch top managers. Their research moved into the twenty-first century. They investigated to what extent the members of executive boards of leading German and Dutch listed companies converged in nationality and educational backgrounds between 1990 and 2005. They did not limit their research to CEOs but included all board members and covered both manufacturing and service companies. In educational background they found, for both countries, a rise in executives with business and

23. Khurana, Searching for a Corporate Savior, 51-80.

24. Mizruchi and Marshall, "Corporate CEOs."

25. Mayer and Whittington, "Euro-Elites.” 
economic studies, at the cost of law studies, whereas a technical background remained common in manufacturing but less so in services. In both countries, boards became more international with mostly European members but also with other nationalities, including a relatively high contingent of American members. ${ }^{26}$

Covering one country over a longer period, Saskia Frye wondered whether a new corporate elite was arising in Germany during the second half of the twentieth century. To answer this question, she examined a sample of CEOs from the fifty largest industrial companies in Germany for every five years between 1960 and 2005. In the period 1960-1980, the German corporate elite, as expected, had a technical background and an in-house career, was appointed in their early fifties, and stayed in the job for between eleven and twelve years. From the 1980s onward, recruitment and career patterns remained fairly stable, on first sight. However, on closer inspection, more movement within the company group took place. The technical education remained important, but business and finance superseded law. The most dramatic change took place in the length of tenure, which dropped from, on average, 12.3 years in 1980 to 8.4 years in 2000. On balance, Freye concluded that "the new career patterns seem to becoming increasingly compatible with the new corporate strategies oriented toward the interests of shareholders and the finance markets." ${ }^{27}$

What this short overview makes clear is that the position of the CEOs in the United States was not stable but changed over time. These changes are not universally seen as positive because of the risk of short-termism. Similar changes were also visible in some European countries, though often at a later period in time, and less clear-cut. More countries need to be included in the comparison. This paper makes a start with the Netherlands.

The Netherlands had a liberal market economy at the start of the twentieth century, but moved toward a more coordinated economy after the disruption of World War One and the immediate postwar economic upheaval. The government began to play a more active role, labor unions became accepted as negotiating parties, and businesses were allowed, sometimes even encouraged, to negotiate cartel agreements. The economic crisis of the 1930s and World War Two further increased economic coordination. With the loss of colonial Indonesia in 1949, the pressure mounted on Dutch industry to create employment for the Dutch workforce. The Dutch economy of the 1950s and 1960s can be characterized as a distinctly coordinated market economy. The company law (structure regime) introduced in 1971 can be seen as an

26. Fioole, van Driel, and van Baalen, "Europeanisation."

27. Freye, "Germany's New Top Managers?" 
underpinning of this collaborative view on the Dutch economy because it obliged supervisory boards to look after the interests of the Dutch society at large and not just the shareholders. The coordinated market economy of the 1950s and 1960s came under pressure in the 1970s, when the world economy stagnated and businesses were unable to fulfil the rising expectations of their various stakeholders. Labor relations became contested territory, while companies struggled to survive, and in some cases went bankrupt, leaving shareholders empty-handed. From the 1980s onward, economic recovery went hand in hand with less government, more flexible and individual labor arrangements, and tougher measures against collusive behavior of companies. The Netherlands moved toward a more liberal market economy. ${ }^{28}$

The change in corporate governance to a liberal market economy became visible in particular since the mid-1990s, when global and European capital-market integration intensified. The stock market became a more important financier for Dutch business, reflected in an increase in the number of initial public offerings and a high volume of share and bonds issues. The market for corporate control became more important once the number of takeover defenses used by listed firms decreased in the 1990s. ${ }^{29}$ Share ownership became more dispersed and international. Institutional investors changed strategies and started to focus more on shares than bonds and more on international than domestic shares. Focus on increasing shareholder value became an important aspect of firms' strategies. In 2004 a new code of conduct for listed firms was introduced (Code Tabaksblat), which included more protection and control for shareholders and more transparency in financial statements. So, although we have considerable insight in how corporate governance changed over time, we need to know more about the impact these changes had on the role of the CEOs, the ones who hold the positions of command.

\section{Methodology and Data}

To find out whether institutional changes did indeed impact the position and role of the CEO, we collected information on a selection of individual chair persons of the executive boards of Dutch companies for the period 1957-2007. To facilitate more context to these descriptive statistics, we also looked at how companies and media present the CEOs and how CEOs themselves perceive their role. With this mixed

28. Sluyterman, Varieties of Cpitalism; Touwen, Coordination in Transition.

29. Jong, Roell, and Westerhuis, "Evolving Role of Shareholders"; Westerhuis and Jong, Over geld en macht. 
method approach we use the strengths of both methods, which serves to give a broader picture. In other words, the qualitative approach gives more meaning to the quantitative approach (frequencies of numbers). The results of both methods then can converge, complement each other, or diverge, thus giving us additional information about our main research question.

For the quantitative part, we collected information on individual CEOs. As a starting point we use a data set containing financial and corporate governance information of all Dutch nonfinancial firms listed on the stock exchange of Amsterdam for the period 1903-2008. ${ }^{30}$ One of the files contains board membership data with five year intervals, starting in 1903, then 1908, and so on until 2007. Important to note here is that Dutch firms have a two-tier board consisting of a managing board and a supervisory board. The managing board is collectively responsible for managing the company. The supervisory board has its own, separate chairperson. From the large data set, we have selected the firms for which we have financial data for twenty years or more. For our research, we need companies that persisted for at least twenty years because one of our research questions is related to length of tenure. For these companies, we added the names of the CEOs on a yearly basis. Our sources are Van Oss Effectenboek for the period 1957-1978 and annual reports for the recent period. The firms have in common that they were all listed at the Dutch stock exchange. The Dutch stock exchange includes the four Dutch multinationals Shell, Philips, Akzo, and Unilever, but also a number of smaller companies with no more than two hundred employees. These companies were either listed in the past in the expectation of a future growth that never happened, or they were slimmed down over the years. It is important to note that relevant information on the CEOs of these smaller companies was more difficult to collect because they were less visible in the media.

From this database we made a further selection on the basis of 11 industry sectors, resulting in a data set of 143 firms and 503 CEOs (see Figure 1). ${ }^{31}$

We divided the sample into five periods of ten years and divided the CEOs among these periods based on when they were first appointed as CEO. The period before 1957 is a special one because it contains only CEOs who were still in position after 1957. The number of CEOs for the period 1957-1966 is relatively small compared to the number of companies in our database for that period because about half the companies

30. For a full description of the database, see the appendix in Westerhuis and Jong, Over geld en macht.

31. We would like to thank the MA students of two seminar groups for their contribution to the collection of relevant data about CEOs. 


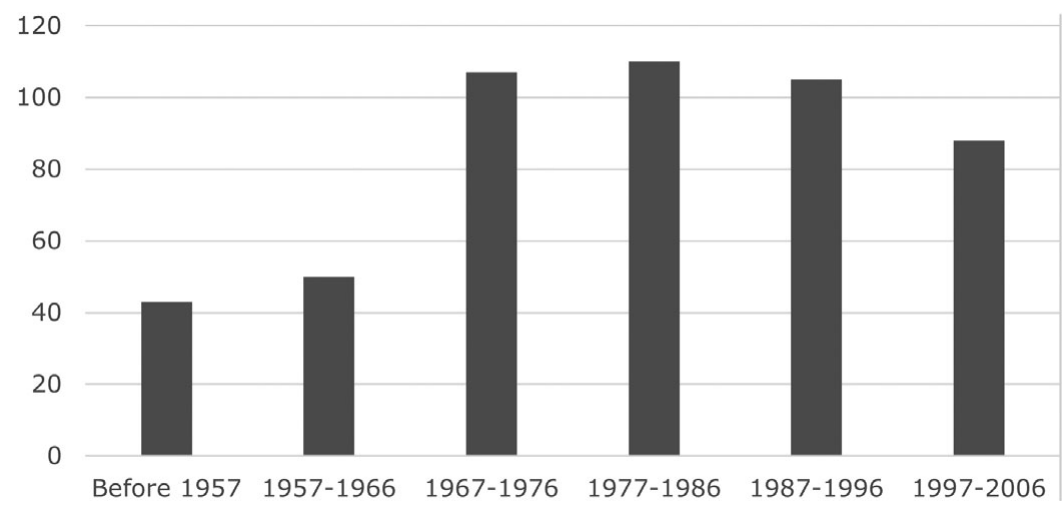

Figure 1 Number of CEOs in the sample, per ten years.

did not identify one person as their CEO in their annual reports, which in itself is an informative aspect of that period (see further in Figure 8).

We collected information about education, average age at the time of appointment, internal or outside appointment, length of tenure, reasons for ending the tenure, age, and nationality. Educational background is relevant because in a CME model one might expect a CEO with a background that reflects the industry sector, for instance, in the manufacturing industry, that could be a technical background and in trade a commercial background. In the LME model, the shareholder value is considered an important measure for CEO success. As a result, one might expect that from the 1980s onward, more people with an economic or financial background are nominated as CEO. We looked at the age at which CEOs were nominated. In the CME model, the CEOs will reach the top of the organization gradually and supposedly rather late in their career. When CEOs can be hired from outside the company, it could easily be somebody who has reached midcareer elsewhere and as a consequence is still younger. We also expect that boards looking for "energetic, charismatic leaders" would be inclined to favor younger persons. We realize other factors might be in play, so age is not considered a hugely informative factor, but it is one of many measures we used. We want to know whether CEOs were internal or external hires. In the CME model, internal selection would be the logical choice. With the LME model, we expect more outsiders to come in because CEOs are not necessarily selected for their inside knowledge but for their appeal to the financial markets, which is an important factor in determining share prices.

Once the CEOs have been nominated, how long do they stay on top? We expect in the LME model shorter terms, in particular for outside CEOs. They are clearly hired to do better than inside managers, so expectations are high, whereas their knowledge about the company is 
Table 1 Number of firms, industries, and CEOs

\begin{tabular}{lcc}
\hline Industry sector & \# firms & \# CEOs \\
\hline Food & 14 & 50 \\
Textile and leather & 15 & 47 \\
Paper & 6 & 20 \\
Publisher & 9 & 30 \\
Chemicals & 10 & 45 \\
Metal products & 8 & 15 \\
Machinery and electronics & 22 & 77 \\
Transport & 11 & 53 \\
Building and civil engineering & 14 & 52 \\
Wholesalers & 30 & 103 \\
Computer services & 4 & 11 \\
Total & $\mathbf{1 4 3}$ & $\mathbf{5 0 3}$ \\
\hline
\end{tabular}

obviously smaller, even though they must have other capabilities, for instance, knowledge about financial markets. High expectations that the outsider can turn around the company may well be too optimistic, and disappointment with the results could easily lead to a quick departure. Finally, what were the reasons for ending tenure? In the CME model, CEOs reached the top late in their career, often after being part of the management board for a number of years. Also, as the board is supposed to act as a team, the role of the CEO is not very prominent. It could be a succession on the basis of age. In this model they stayed on until retirement, unless forced out by illness or death. In contrast, in the LME model in which shareholders have a prominent say, we expect individual CEOs to experience greater scrutiny. Shareholder capitalism is often seen as "impatient capital," and we expect this impatience to lead to more dismissals, in particular of external hires.

To collect the required information, we used various sources such as newspapers, biographical books, who's who, and so on. Despite all efforts, we were not able to find all required information. In Table 2, missing data are shown as the number of CEOs. For forty-seven CEOs we could not find the year of birth, and therefore we could not measure the CEOs age when he or she was appointed CEO. For education we looked at the level of education (university or no university) and at the direction of education. Unfortunately, the number of CEOs for whom we could not find information on their level of education is relatively high (168 of the 503 CEOs). Of these 168 CEOs for which the level of education is missing, 132 are from the earlier periods (between 1957 and 1986).We assume that many of these earlier CEOs ended formal education after finishing high school and/or followed industry-specific training or internships in related companies because this was a familiar pattern in the 1930s, the period in which the CEOs of the 1950s and 1960s grew up. We assume that these 168 CEOs had no university 
Table 2 Missing data

\begin{tabular}{lc}
\hline Information category & \# CEOs without information \\
\hline Start year & 0 \\
End year & 0 \\
Length of tenure & 0 \\
Year of birth & 47 \\
Education: level & 168 \\
Education: direction & 198 \\
Internal/external hiring & 19 \\
Reason for turnover & 12 \\
Gender & 0 \\
Nationality & 0 \\
\hline
\end{tabular}

degree because academic titles were routinely recorded in corporate annual reports during the twentieth century.

For 305 CEOs, mostly with a university degree, we have traced the direction of their education. We make a division between law, economics, technical, and other. Economics include, besides economics, econometrics, trade, and MBA. Technical studies are all studies for which the graduate gets the Dutch title "ir" (ingenieur) and includes chemical, electrotechnical, mechanical, and mining engineering studies. The category "other" is rather diverse and includes psychology, sociology, political sciences, finance, and accountancy.

For the qualitative part of our research, we have explored the views on CEOs, including aspects of soloist versus team player, serving interests of shareholders or all stakeholders, and the importance (or not) of in-depth personal knowledge of the business. Consistent with the LME model are CEOs who are soloists, who predominantly serve the shareholders and have a general or financial background. In contrast, CEOs of the CME model are supposed to be team players, serve all stakeholders, and have an in-depth knowledge of the business. We have, first of all, looked at contemporary interviews with CEOs. We searched in newspapers and management journals. For the 1950s and 1960s, it was not easy to find interviews or biographies because, at that time, the person of the CEO was not considered of great interest. In fact, this lack of available interviews illustrates the very point we are making: that the attention was more on companies and their collective decision-making than on the individual views of those leading them. We also included observations by management consultants and speeches by CEOs, though we realize that those speeches may well have represented a company view rather than a personal view. In this context, it is also important to note that, over the whole period, references to American management ideas was omnipresent in Dutch newspapers and journals. For the 1980s and 1990s, many more interviews were available, illustrating the enhanced interest in the personal views of CEOs in the 


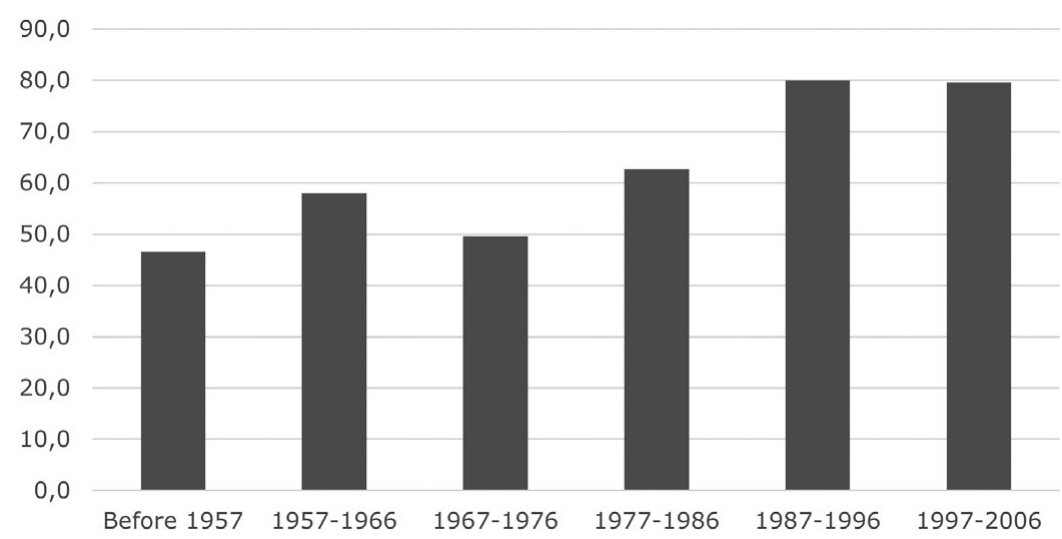

Figure 2 CEOs with university degree (\%).

Netherlands as well. Of course, we are aware that interviews tell us as much about the journalist who conducts the interview as about the interviewee, but that is not a problem because we are interested in what is being discussed in different periods of time. Therefore, the interviews give us a time-bound perspective. All direct CEO quotes are from CEOs in our database, apart from the quotes of Paul Polman, who did not become CEO of Unilever until after 2007, when our database ends.

\section{Changing Role of the CEO: Quantitative Approach}

In the introduction, we identified educational background as an interesting criterion to characterize CEOs. Vinke, who analyzed a data set of listed and nonlisted companies, shows that 25 percent had a university degree in 1950. ${ }^{32}$ For our sample, we found that the percentage of CEOs with a university degree increased substantially from around 50 percent until the mid-1970s to 80 percent after the mid-1980s ( see Figure 2).

In Figure 3, we have further analyzed the CEOs with a university degree. Two things stand out. First, CEOs with a university degree in economics increased from around 20-25 percent in the 1950s and 1960s to almost 40 percent in the latest period. Only one of them obtained an MBA. However, we know that many CEOs did additional management courses, for instance, at INSEAD. It was not possible to include these courses, which were often offered within the companies, in our data.

Second, with a percentage of around 40 percent, a technical study remains important during the whole period, and in the period before

32. Vinke, Maatschappelijke plaats, 292. 


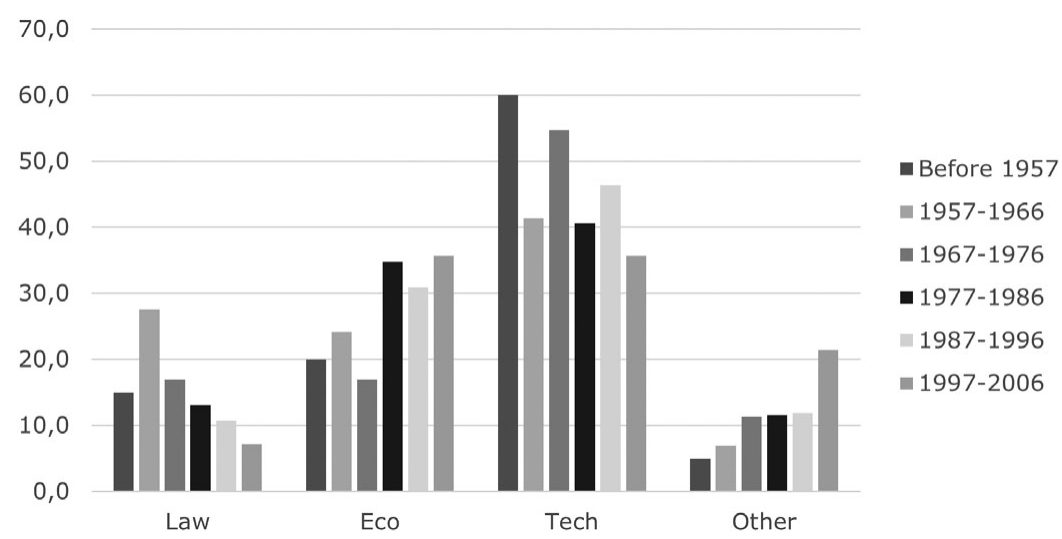

Figure 3 Educational background (\%).

1957 and between 1967 and 1976, it even increased to 60 percent. This might be related to the sectors that we focus on. Thus, we found that in the industrial sector (chemicals, metal products, machinery and electronics, and building and civil engineering) a CEO with technological knowledge was still considered an asset, whereas in services CEOs more often had a background in economics. The educational background of Dutch managing directors has been subject to two earlier studies covering the years 1984 and 1993. Both studies noticed an increase in academic titles. Interestingly, in both studies the authors expected a decline in the number of CEOs with a technical background, and in both cases their results did not show such a decline, though the authors still expected such a decline to show up in the future. ${ }^{33}$

The rise of CEOs with an economic background did not come at the cost of a technical background, but it meant CEOs with a background in law decreased. Their numbers decreased from almost 30 percent in the period 1957-1966 to 8 percent in the period 1997-2006. The category "others" increases during the whole period, which highlights the growing variety of academic studies. All in all, the educational background shows only a partial shift toward an LME CEO model because of the continuing significance of a technical background. These results are comparable with the findings of Freye with regard to the German corporate elite, for whom technical studies remained important while law studies were superseded by business and finance. ${ }^{34}$ The changes in educational background show some similarity with those in Switzerland, where CEOs also had less often a background in law and more

33. Lawrence, Management in the Netherlands, 34; Icke, Mokken, and Schijf, Technologie \& Management, 20-23, 51-55.

34. Freye, “Germany’s New Top Managers?” 17-18. 


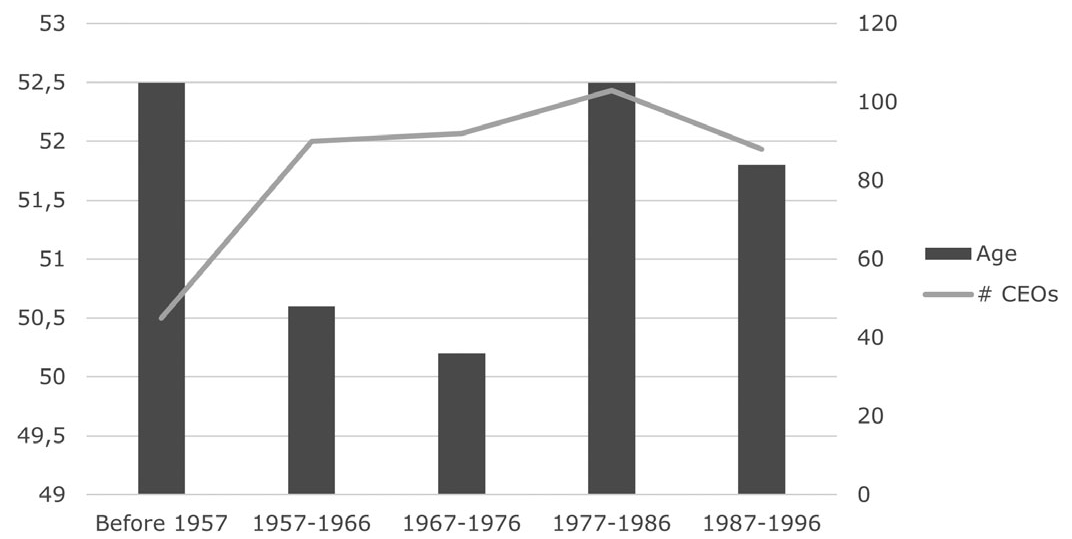

Figure 4 Average age at the moment of appointment.

often one in economics, whereas technical studies also remained important. ${ }^{35}$

In contrast to what we expected on the basis of the CME-LME CEO model, we do not find a significant change in the average age at which managers become CEOs. As Figure 4 shows, the average age fluctuates between 50 and 52.5 years.

During the 1967-1976 period, the CEOs were, on average, nominated at the youngest age. We have as yet no explanation for this finding, but it could be related to the swinging sixties, when age was no longer considered a sign of wisdom and a right to authority. Interestingly, Freye found a similar drop in average age on appointment to the CEO position in her sample of German CEOs. The average age of German CEOs dropped from fifty-three years in 1960 to forty-nine years in 1980, and it then started to move up again to fifty-two years in 2000. In recent years, the average age at the moment of appointment to the CEO position dropped again to 50.7 years in $2005 .{ }^{36}$ In our database we also see a drop in average age of about a year between 1977-1986 and 1987-1996.

A final aspect of the question of who is on top is the question of whether the CEO followed an internal career or was hired from outside. Managers who were hired from outside and appointed one to two years in the board as a preparation before becoming CEO, were classified as external hires. As shown in Figure 5, we found that over the whole period, CEOs are mostly hired from inside, often after making a career within the organization; only in the period 1997-2006 is internal and external hiring almost equal, whereas the percentage of CEOs that had made a career within the company had been around 85 percent in the

35. Bühlmann, David, and Mach, "Swiss Business Elite."

36. Freye, “Germany's New Top Managers?” 23. 


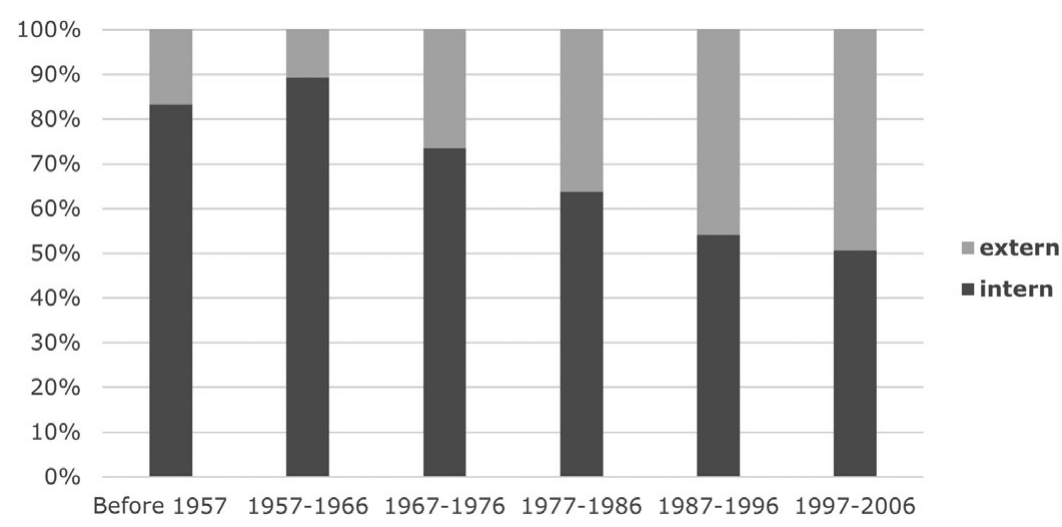

Figure 5 Internal versus external hiring (\%).

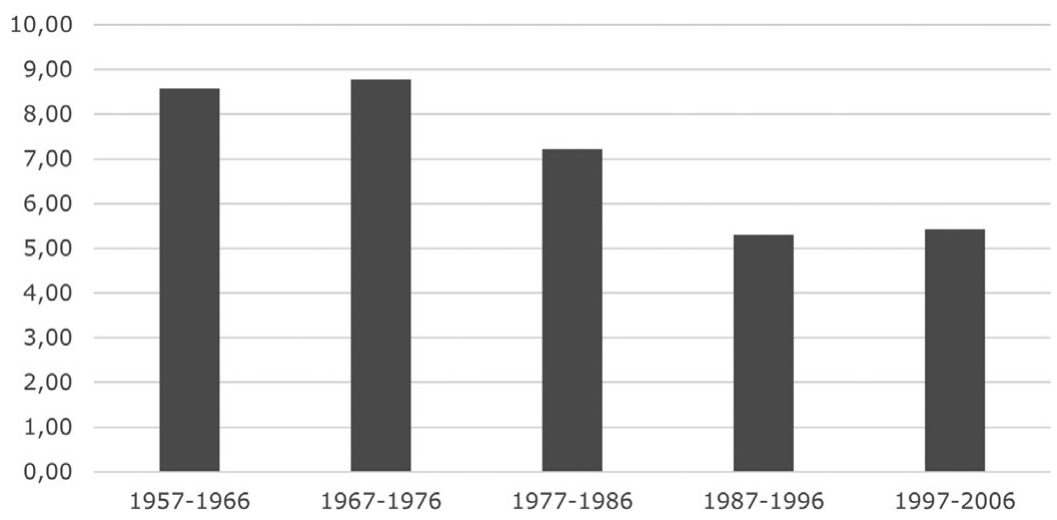

Figure 6 Average length of tenure of CEO in years.

1950s and 1960s. So, hiring externally has become more popular since the late 1960s.

Now that we have a clearer picture of the personal attributes of the CEOs, including a modest shift in educational background (more economic degrees), little change in age at appointment, and a clear increase in external hires, we turn to the question how long they stayed on top once they had been nominated. Figure 6 shows that the average tenure of the CEO has declined over the last 50 years from 8.6 years in the period 1957-1966 to 5.4 years between 1997 and 2006.

The drop in length of tenure started already in the mid-1970s, so earlier than we had expected on the basis of our CME-LME CEO model. There seems to be a clear link with the economic difficulties traditional Dutch industries such as textiles and metals were experiencing during that period. We had expected a further drop in the last period, but that did not happen. Over the whole period, the length of tenure of the Dutch CEOs in our sample was shorter than Freye found for the German 


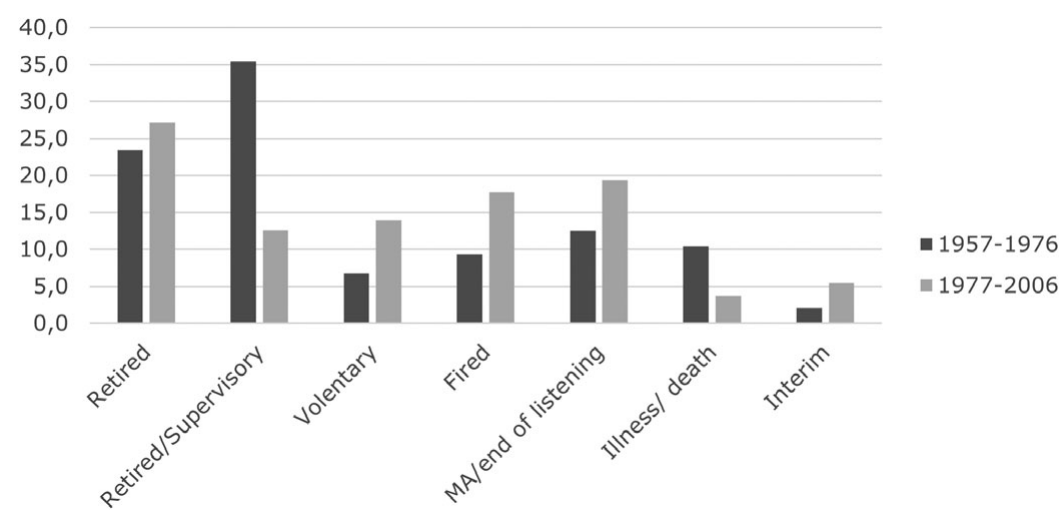

Figure 7 Reasons for CEO departure (\%).

CEOs, but she also noticed a substantial shortening of the tenure between 1980 and 2000, from 12.3 to 8.4 years. ${ }^{37}$

In the LME model, CEOs are more likely to be dismissed for poor performance than in the CME model. If it is correct that the Netherlands moved to a more LME model, we would expect an increase in forced dismissals. For the breakdown of reasons for departure, we divided our period into two subperiods-1957-1977 and 1978-2006-and we identified seven different groups: (1) CEOs who retired; (2) CEOs who retired and moved to a seat on the supervisory board; (3) CEO's who left the firm voluntarily; (4) CEOs who were forced to leave; (5) CEOs who lost their position due to a merger or acquisition; (6) CEOs who died or went ill; and finally (7) interim CEOs (see Figure 7).

Figure 7 shows that the categories "retired" and "retired plus a seat on the supervisory board" were very high (59 percent) in 1957-1977, but, although they remained high, their share declined to around 40 percent. In particular, the category "retired plus a seat on the supervisory board" declined substantially from 35 to 13 percent. The percentage of forced dismissals doubled between 1957-1977 and 1978-2006, from 9 to 18 percent, but CEOs who left the firm on a voluntary basis also doubled between the two periods, from 7 to 14 percent. Interestingly, the percentage ofCEOs who had to leave due to a merger or acquisition, which might be seen as a kind of forced turnover, increased considerably after 1978. Steven Kaplan found, for CEOs in the United States, that in the 1970s about one in ten CEOs was dismissed, a percentage that is very similar to the 9 percent we found in our sample for the period 1957-1977. In contrast, between 1998 and 2005, about one in six CEOs in the United States was dismissed, so more than 16.7 percent. For the longer period of 1977-2006, our Dutch sample of CEOs shows a dismissal percentage of

37. Ibid., 24. 
17.7, again very similar. ${ }^{38}$ Our database shows that the rise in dismissals started in the second half of the 1970s and was initially linked to the worsening economic circumstances in that period, but was later on also in line with a move toward the LME CEO model.

Finally, we also noted information on gender and nationality. Researching female board members in the Netherlands, Heemkerk and Fennema found that their numbers increased from the 1990s onward, but mostly in the supervisory boards and less so in the managing boards. In the managing boards, female members were mostly on their own and seldom in prominent positions. ${ }^{39}$ In line with these findings, we found only 2 female CEOs among our total of 503, despite the general increase of women in board positions. Dutch business has always been internationally oriented, and multinational companies in the Netherlands acted as agents of institutional change. ${ }^{40}$ For that reason, we would have expected a rising number of international CEOs. Fioole, van Driel, and van Baalen also concluded that in Dutch companies the number of international board members increased in recent decades. Comparing the internationalization of executive boards of large companies in fifteen European countries, Veen and Marsman found that Dutch managing boards had relatively large numbers of international members in 2005. ${ }^{41}$ Nevertheless, our database shows that the position of CEO remained predominantly in Dutch hands, at least until 2007. Spread over all periods, only 17 of our 503 CEOs came from abroad, including 7 from neighboring Belgium, 4 from the United States, 2 from Britain, and 1 each from Switzerland, Germany, Italy, and Sweden. The preference for Dutch CEOs suggests that their role in negotiating with the relevant Dutch stakeholders, including government and trade unions, is still considered of prime importance and that Dutch persons are supposed to fulfill that role more easily in a Dutch context. However, this suggestion is pure speculation because we do not know the motivations behind CEO nominations.

Following up on our CME-LME CEO model, we are interested to know whether the externally hired CEOs have another profile than the internally hired ones. Indeed, for the whole period, we see that the externally hired CEOs are more often dismissed or released due to a merger or acquisition compared to internally hired CEOs. The latter remained more often in office until retirement (see Table 3).

38. The figures of Kaplan are quoted in Mizruchi and Marshall, 153. See also Kaplan, "Are U.S. CEOs Overpaid?”

39. Heemskerk and Fennema, "Women on Board.” In a recent study on Swiss corporate boards, Ginalski concluded that female presence remained low and that top positions were out of reach for women. Ginalski, "Who Runs the Firm?"

40. Sluyterman and Wubs, "Multinationals."

41. Veen and Marsman, "How International Are Executive Boards," 193. 
Table 3 Comparison between internal and external hires: reasons for departure

\begin{tabular}{lcccc}
\hline & Retired & Retired and supervisory board & Fired & M\&A \\
\hline intern & 30.9 & 26.4 & 11.7 & 11.1 \\
extern & 18.1 & 11.9 & 18.1 & 28.1 \\
\hline
\end{tabular}

Internally hired CEOs also remained in their CEO position for a longer period, on average, three years more than externally hired CEOs. When breaking down the whole period in subperiods of ten years, this picture is confirmed in particular for the period 1997-2006 in which tenure of externally hired CEOs is, on average, 4.1 years compared to 7.3 years for internally hired ones.

Thus, based on our data we can conclude that the average length of tenure has decreased, as did retirement by illness and death. On the other hand, voluntary and forced retirement increased substantially, as did turnover due to mergers and acquisitions. Sometimes CEOs became victims of their own ambitious merger plans, and sometimes mergers and acquisitions could be considered a logical consequence of underperformance of the CEO. We found no marked difference between the various industry sectors. All in all, with regard to external hiring, length of tenure, and reasons for departure, we can see at least a partial shift from the CME to the LME model of CEO as we formulated in the introduction. In the next section, we will discuss the qualitative aspects.

Views on the Role of Dutch CEOs during the 1950s, 1960s, and 1970s

After World War Two, government, business, and labor unions worked closely together to rebuild the country. Government supported companies that, in turn, were supposed to provide employment for a growing population. The dominant Christian democrat parties were looking for a middle ground between free enterprise and the socialist-inspired state regulation. Key in that search was a harmonious collaboration between employers and employees, including the establishment of works councils and more generally the democratization of the company. In this context, large listed companies were no longer seen as private vehicles for profit maximization but as the engines of economic growth that benefited society at large. ${ }^{42}$

In 1959 the Dutch management consultant Dirk Horringa wrote a book about leadership and organization in Dutch companies. ${ }^{43}$

42. Sluyterman, Dutch Enterprise, 133, 144-146.

43. Horringa, Leiderschap en organisatie. 
He mentioned that it was usual in the United States for companies to have one president and a number of vice presidents who served under the president. Some companies in the Netherlands had a similar structure of a chief executive officer (often termed "presidentdirecteur") with subordinate executive directors, but many other companies were led by a team of executives of equal standing. The directors with different capabilities divided the tasks according to their preferences and abilities, and as a consequence such a team offered a broader set of capabilities than one person ever could possess. Horringa conceded that leadership with a team had the disadvantage that it was unclear who was personally responsible for which decisions. However, a team offered better continuity, and the process of consultation helped new managers get gradually acquainted with their future responsibilities. To make his point even stronger, Horringa stated that the American managing consultant Peter Drucker argued in his book Practice of Management (1954) for leadership teams. ${ }^{44}$ Indeed, Drucker wrote in his famous book: "There is only one conclusion: the chief-executive job in every business (except perhaps the smallest) cannot properly be organized as the job of one man. It must be the job of a team of several men acting together." Drucker explained that this conclusion might sound like "heresy" in the United States but was quite common in Europe. He added: "Actually there is a serious doubt whether the successful business ever used the one-man concept." 45

In the Netherlands, the idea that a team of executives was jointly responsible for running the company was so much accepted that companies frequently did not even identify one person as the chairman of the executive board in their annual reports, as we can learn from Figure 8, which is based on our largest sample.

No doubt, in practice, some of the directors must have led the board meetings, but this role was often not clearly marked. In cases in which companies did highlight one person as "chairman", the role was often considered modest. The chairman was primus inter pares. He chaired the meetings, but the other managing directors were not subordinate to him. Even the chairman of the largest company in the Netherlands, Royal Dutch Petroleum Company (the Dutch part of the Royal Dutch/ Shell Group), John Loudon, considered himself to be primus inter pares. The American magazine Time interviewed Loudon in 1960 and wrote about him and his fellow directors:

44. Ibid., 82-84.

45. Drucker, Practice of Management, first published in 1954, quotes from the 1968 edition by Pan Books, 204, 211. 


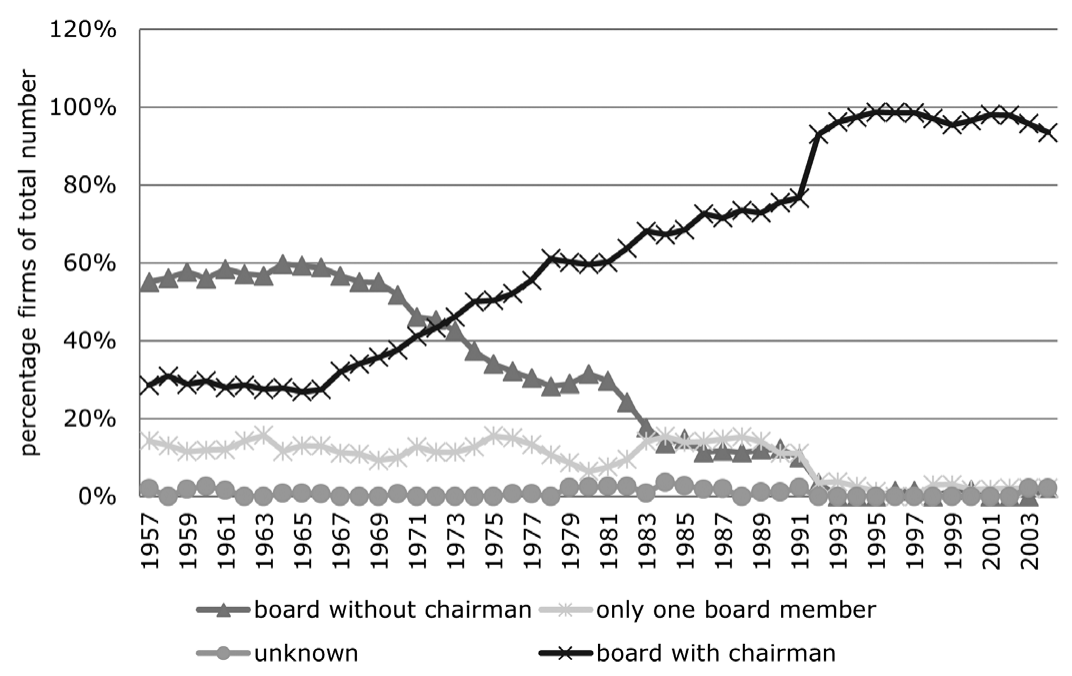

Figure 8 Governance structure of executive board, 1957-2004 (\%).

Of a far different stripe than the rough and ready tycoons of the past, they are subdued, cautious, and vastly competent in the modern committee manner.... Since the Group has an unwritten rule that decisions are never forced to a vote, Loudon as the primus inter pares, tactfully arbitrates differences, suggests lines of agreements, sounds out his fellow directors. ${ }^{46}$

In 1969 six leaders of Dutch large companies were interviewed by the Dutch journalist A. C. W. van der Vet. The interviews were very broad about companies and society, the role of leaders, and their own role in leading the company. In the 1960s the democratization of the company was high on the agenda of socialist and social-democratic parties, and all CEOs readily agreed that employees were important and that companies existed for the good of society and not just for the shareholders. They also were quite willing to listen to employees and to give employees some say about the running of the company in direct relationship to their field of expertise. That employees would have a say in the boardroom, however, was considered quite unnecessary and indeed unwelcome. ${ }^{47}$

Asked about the "loneliness at the top," several CEOs mentioned that decisions were taken in the board after extensive discussions and after consultation with the specialists in the company. Jan Meynen from AKU (later Akzo) mentioned that in a large company collective decision taking is absolutely necessary. ${ }^{48}$ Even Albert Heijn, who stood

46. Time Magazine (Atlantic edition) 75, No. 19, May 9, 1960, 92-102.

47. Vet, Per slot van rekening.

48. Ibid., 127. 
at the head of his (listed) family company, pointed to the collective responsibility of the managing board, in this case consisting of four people, two representatives of the Heijn family and two outsiders: "Decisions we take collectively." ${ }^{49}$ Some CEOs admitted that taking entrepreneurial decisions could be stressful, but they did not seem to be very concerned about demanding shareholders. They felt most anxious about effects on their workforce, in several cases referring to the dismal crisis of the 1930s. All named the continuation and growth of their company as their most important responsibility as entrepreneurs.

In the 1970s the narrative changed. Labor unions became much more antagonistic toward the employers, who in turn were less willing to listen to employees' demands because they struggled to keep their companies afloat under harsher economic circumstances. Dutch government often sided with the labor unions. Fed up with trade union criticisms, F. O. J. Sickinghe, CEO of FME-Stork, wrote in an article in Elsevier's Weekblad that works council should take over the whole responsibility of running the company if they thought they could do a better job. However, he warned that they would still face the same economic problems that the present company leaders were experiencing. ${ }^{50}$ In 1976 nine CEOs of multinational companies took the unusual step of sounding the alarm bell over the deteriorating business climate by writing an open letter to the Prime Minister, Den Uyl. ${ }^{51}$ The CEOs were no longer prepared to guarantee employment, not even in exchange for lower wages, because rising wages and increasing social spending had greatly diminished the profitability of their businesses. In a way, their warning came too early, and the public reaction to their letter was mostly negative. The public mood toward CEOs became even more negative when an increasing number of companies had to cut employment and some of them failed altogether.

\section{View on the Role of Dutch CEOs during the 1980s and 1990s}

In 1987 the American business magazine Fortune announced the new chairman of Royal Dutch/Shell, Lo van Wachem, with the following introduction: "In the boardroom at Royal Dutch/Shell, chairmen come and go. And hardly anyone, including people who make it their business to track such things, even notices. 'More than most big companies, Royal Dutch/Shell is very much run by committee,' observes a respected British oil analyst. 'Whoever is at the top, they just carry on being good at what they do." ${ }^{52}$ This quote from Fortune would suggest

49. Ibid., 68.

50. Elsevier's Weekblad, Vol. 31, no. 46, 15 november 1975.

51. Sluyterman and Wubs, Over grenzen.

52. Fortune, Vol. 130, no. 8, August 3, 1987, 22. 
that nothing much changed in board dynamics between 1968 and 1987. However, there were subtle changes, for instance the greater emphasis on entrepreneurship not only at the top but throughout the whole organization. To encourage entrepreneurship within large companies, managers of the operating companies were given personal responsibility for their budgets and performance. In the meantime, the board members were still considered collectively responsible, but the role of the leader became more visible. ${ }^{53}$ These changes also appear in another series of interviews, written by Frank van Empel and John Jansen van Galen and published in 1985.

As in the 1960s, the continuity of the company was an important topic in this series of eleven interviews. In the late 1970s and early 1980s, the world had gone through an economic recession, and as a consequence companies, small and large, had struggled to survive, and not all had succeeded. However, in 1985 the feeling dominated that the worse was behind, though unemployment was still high, and the companies of the chairmen (still only men) that were interviewed belonged to the survivors. Asked about the challenges ahead, all chairmen remarked that profitability needed to go up in order to create growth again. They were quite adamant that taxes and social benefits should go down because production costs in the Netherlands were too high for the companies to remain internationally competitive. The interviewers asked whether higher profits would lead to more employment in the Netherlands. Interestingly, none of the entrepreneurs offered the prospect of more employment in their own companies, though they expected that the growth of their companies would lead to growth and employment in supporting industries. They did not feel it was their responsibility to provide employment. ${ }^{54}$

In several interviews the chairman highlighted the importance of decentralization and entrepreneurship in lower levels of the organizations. Jaap Endtz of Hollandsche Beton Groep (HBG) explained that everybody in the company, from high to low, was supposed to be an entrepreneur. The executive board had the task to coordinate and sanction plans and provide financial means. He did not mention whether or not the executive board decided collectively, nor was the question asked. ${ }^{55}$ However, some other chairmen were asked who was taking the important decisions. Again, they mentioned consultation and teamwork. Aarnout Loudon of Akzo told the interviewers that, in general, in the Netherlands there was collegial

53. Sluyterman, Keeping Competitive, 284.

54. Empel and Jansen van Galen, Captains of Industry.

55. Ibid., 135. 
responsibility, in contrast to the United States. ${ }^{56}$ However, at the same time several chairmen underlined that, at the end of the road, the chairman decides and that this can be "lonely." Wisse Dekker, from Philips, mentioned that he made use of the expertise of the members of his executive board, but he expected his proposals to be accepted, and he added that a chairman has a lot of influence: "That is logical and everybody accepts it." ${ }^{57}$ Of course, this may have been equally true in earlier years, but the interesting point is that Wisse Dekker underlines his individual responsibility and power, whereas in the 1960s those were underplayed.

Nearly ten years later, in 1994, journalists of the Dutch liberal newspaper NRC-Handelsblad interviewed fourteen CEOs to ask them, among other things, what they intended to do for the lingering problem of unemployment in the Netherlands. Tellingly, the title of the series was "The Decision Makers" (De beslissers). Clearly, the journalists looked upon the CEOs as the ones who made the strategic decisions in the company. Aarnout Loudon from Akzo, who was also interviewed in 1985, mentioned that his voice was decisive in a stalemate situation, but that normally the views in the board would grow toward a shared position. About two thirds of the interviewees saw themselves as the leaders of the company, as the ones who took the strategic decisions and decided upon the future direction of the company. They formulated targets in terms of growth in sales and profits, and growth in sales was often achieved through acquisitions rather than internal growth. Some of them formulated quite stringent profit targets. Asked by the journalists whether their companies would provide more employment in the Netherlands, all CEOs mentioned that this was not their responsibility, and in fact, most of them mentioned that labor costs in the Netherlands were too high and the labor market too inflexible. The journalists themselves concluded from the interviews that, in the past two decades, the CEOs had been competent managers, relying on calculations and financial figures, but the time had come for a new kind of leader, for creative persons with inspiring ideas to create lucrative innovations. Interestingly, the journalists posed no leading questions about incentive pay structures or high remunerations for CEOs. ${ }^{58}$

56. Ibid., 47 .

57. Ibid., 34 .

58. Series of interviews by Max Christern, Wabe van Enk, Michel Kerres, Maarten Schinkel en Michelle de Waard in the Dutch national newspaper NRC Handelsblad, 15, 22 (jhr. Mr. A.A. Loudon), and 29 January 1994, 5, 12, 19 and 26 February 1994, 5, 19 , 23 and 26 March 1994 and 2, 16, 23 and 30 April 1994 (comment ABN AMRO managing director Hazelhoff). 
These discussions arrived later in the 1990s. The introduction of stock option plans for senior staff, in combination with buoyant share prices, led to societal concerns about rising income inequality. In 1997 the Dutch prime minister, Wim Kok, spoke about "exorbitant selfenrichment" in companies. ${ }^{59}$ As the highest earners in their companies, the CEOs faced the strongest criticism. The complaints reached fever pitch in situations in which companies showed disappointing financial results while CEOs still received high earnings or were sent away with substantial severance payments. The high incomes were defended by pointing out the unique leadership qualities CEOs were supposed to possess, even though traditionally the Dutch CEOs acted as part of a team.

During the booming second half of the 1990s (at least share prices were booming), the Dutch press became interested in identifying "iconic leaders," in this respect following the American press. Some Dutch CEOs were highlighted as being special because their companies were successful. The press put them on a pedestal, and they may well have started to believe themselves that the successes of their companies were their personal achievements. However, when the results of their companies started to falter, or when accounting irregularities surfaced, they experienced the full blast of public condemnation. A case in point was the CEO of Ahold, Cees van der Hoeven, who was initially hailed as a truly entrepreneurial CEO but later condemned as the quintessential "narcissistic CEO" after accounting irregularities in the U.S. subsidiaries and elsewhere came to light. Cees van der Hoeven later admitted that the admiration lavished on him during the prosperous years may have clouded his judgement. ${ }^{60}$ In the twenty-first century, the Dutch press was less inclined to present CEOs as heroes.

In 2005 Royal Dutch Shell formally introduced the British one-tier board and the figure of the CEO, who can be held personally accountable if things go wrong. Jeroen van der Veer was the first to be officially CEO of Royal Dutch Shell Plc. He commented cheerfully: "My head is on the block." However, at the same time he underlined the importance of teamwork in the whole company. ${ }^{61}$ Hans Wijers, who, after stepping down as CEO of Akzo Nobel, became chairman of the supervisory board of several Dutch companies, remarked in 2016, "The CEO was the primus inter pares. Nowadays everything changes so quickly that you need more powerful leadership from CEOs.”62

59. Sluyterman, Dutch Enterprise, 213.

60. Smit, Het drama Ahold; Jong, DeJong, Mertens, and Roosenboom, "Royal Ahold," 595-619.

61. Sluyterman, Keeping Competitive, 281, 434-435.

62. Interview with Hans Wijers, Management scope, 3 February 2016: https:// managementscope.nl/magazine/artikel/705-hans-wijers-corporate-governance. 
The annual reports of the 1960s proudly showed products and production facilities in the Netherlands as well as in foreign countries. There may be a picture of a managing director visiting overseas activities, but otherwise the board members were just names. In contrast, in the 1990s the annual reports contained pictures of board meetings or quasi informal gatherings of the board. The readers can see the whole team, but often the chairman of the executive figured more prominently, with a personal picture as well as a "personal introduction" to the report. Discussing the situation in the United States, Arijit Chatterjee and Donald Hambrik consider large CEO pictures and personal introductions as a sign of CEO narcissism. ${ }^{63}$ This may be true for the situation in the United States, but in the Dutch situation it could just as well be a sign of changing PR fashion rather than CEO preference. It certainly underlines the greater emphasis on the person of the CEO. Moreover, in the 1990s the word "CEO" started to crop up in the Dutch financial newspaper Financieele Dagblad, as we can see in Figure 9. ${ }^{64}$

With regard to the choice between serving the interests of shareholders or all stakeholders, Dutch CEOs sent out mixed messages. Many CEOs continued to underline the importance of all stakeholders as well as the focus on long-term success, even during the 1990s. However, the term "shareholder value" certainly entered the debate and was introduced in annual reports to measure a company's performance. Shareholders were mentioned more prominently than in the 1960s and 1970s, but other stakeholders were not entirely forgotten. The dot-com crisis of 2001 and the financial crisis of 2008 both led CEOs in the Netherlands to point out the importance of long-term strategies. Not surprisingly, in a 2014 series of TV interviews (later published), all CEOs were adamant that they worked for the long-term success of the business. Most of them were also, for different reasons, critical of the culture of bonuses and shareholder value. ${ }^{65}$ However CEOs may want to think long-term and advocate the interests of all stakeholders, including the climate, for leaders of listed companies the shareholders and their demands remain a daily reality.

Very outspoken about sustainability was Unilever topman Paul Polman. In a question and answer session in Harvard Business Review, he explained that the financial crisis of $2008 \mathrm{had}$ made it clear to him that the purpose of business should first and foremost be to serve

63. Chatterjee and Hambrick, "It's All about Me," 351-386.

64. Westerhuis and Jong, Over geld en macht, 194.

65. Verbraak, Kijken in de ziel. 


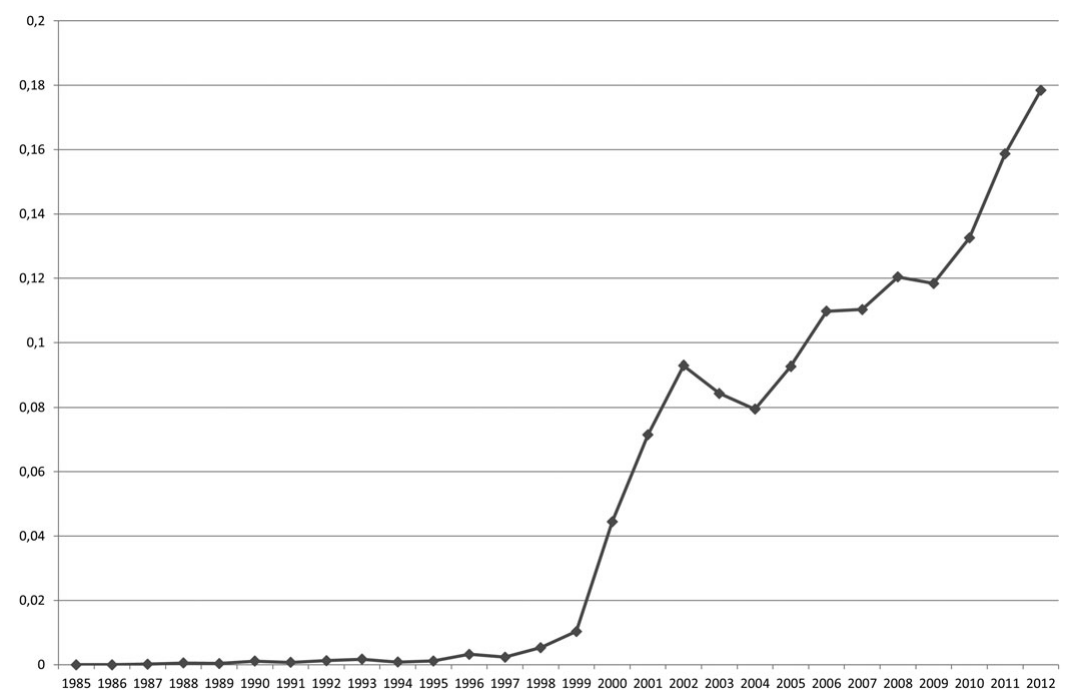

Figure 9 The use of the word "CEO" in relation to the words "bonds" and "shares."

society: "It is, after all, not possible to have a strong, functioning business in a world of increasing inequality, poverty, and climate change. The good thing is that, next to our moral obligations to address the global challenges, there is an enormous business opportunity. That is the equally exciting part." 66 Interesting in this quote is the emphasis he places on "moral obligations," and the same is visible in recent studies on organizational management. The new subjects recommended to be studied include moral leadership and authenticity. Also, the importance of teamwork and the relation between leaders and followers are highlighted. ${ }^{67}$ Polman took clear measures to materialize in Unilever what he considered to be his moral obligations, however, not all shareholders were convinced about the merits of his approach, and one competitor tried (in vain) to force a hostile takeover. At the same time, environmental campaigners remained sceptical about his measures. ${ }^{68}$ That raises questions: Was his leadership not effective, or was he too far ahead of his time? Will the financial crisis of 2008, in hindsight, turn out to be a new turning point in how the role of the CEOs is perceived and defined? And perhaps more stringent questions can be asked as the consequences of the COVID-19 crisis unfold.

66. Harvard Business Review, November 2017, Q\&A with Paul Polman, https// hbr.org/2017/11/the-future-economy-project-qa-with-paul-polman

67. Riggio, "Management and Leadership."

68. Smit, Het grote gevecht. 


\section{Conclusion}

In this paper we examined the figure of the CEO in the Netherlands in its historical context. We assumed that there was a shift in the role and perception of the CEO and that this shift was related to broader institutional changes in Dutch capitalism. To explore this link further, we formulated a set of suppositions with regard to CEOs in liberal market economies (LME) and those in coordinated market economies (CME). We tested the two models with information collected for a substantial sample of CEOs combined with interviews printed in the press and journals (mixed method). The results of the quantitative and qualitative approach did not diverge, but they certainly did not show complete convergence either. So, how the CEO was presented in the media suggested a stronger change in the role and characteristics of the CEO than the quantitative data reveal. This might have to do with the dominance of American ideas on management practices in the Dutch media.

The CEO of the 1950s and 1960s corresponds to our CME model: For more than half the companies, an individual CEO was not even identified in their annual reports. Teamwork was considered important; the CEO was perceived as primus inter pares. Furthermore, CEOs often followed a long-term career in one company and stayed on as CEO for eight or more years, until they retired or died or became ill. Only 10 percent was forced to retire. Around 50 percent of CEOs had followed an academic study, and the majority of them had acquired a technical capability. In interviews about the company, they underlined the importance of employees and the provision of employment, and mentioned the other stakeholders in passing.

Mayer and Whittington found that the top British, French, and German managers were not very different in 1993 compared to 1983. If there were significant changes, they happened after that date. For our data on Dutch CEOs, we found that shifts began to take place from the mid-1970s onward, and some of those changes, for instance the increase in dismissals, were clearly linked to the economic depression in that period.

The answer to the question of whether, during the 1990s, Dutch CEOs showed conformity to the LME model of the CEO is more mixed. We found less internal hiring, shorter tenures, and more cases of dismissals and departures as a consequence of mergers or acquisitions, which all point to a move in LME direction. Nevertheless, in nearly 40 percent of the cases, the end of tenure was still the result of reaching the retirement age, though the number of CEOs that subsequently became members of the supervisory board decreased. We did find a 
clear difference between internally and externally hired CEOs in one particular respect: The externally hired CEOs were more often dismissed or saw their tenure ended due to mergers and acquisitions. On the whole, there was a substantial rise in academic backgrounds, with the number of CEOs with a background in economics increasing, but many still had a technical background. In interviews, CEOs more often underlined their leadership role instead of teamwork and collective responsibility. More emphasis was placed on the interests of shareholders but still in the context of the interests of all stakeholders. Often the CEOs continued to emphasize the importance of long-term strategies.

All in all, we certainly see a movement in the direction of the LME model, but there remain CME elements. The changes in the Netherlands were comparable with those in Germany. In the Netherlands, some CEOs were hailed as "saviours of the companies" in the second half of the 1990s by the media who were probably inspired by the American example. However, the admiration lasted only a short period. It basically ended with the dot-com crisis in 2001. Instead, the increased remuneration of CEOs continues to be a bone of contention until this day. The partial shift from CME to LME model could be seen as a sign of American influence, but a similar process took place in the United States under the influence of globalization and financialization, which would point to the fact that both countries responded to the same economic forces.

It is clear that the generalizations of Hall and Soskice captured a moment in time and described the developments in the 1990s. Their analytical framework remains useful because it is parsimonious and flexible. It works well as a common starting point to compare different periods as well as different countries, and it highlights the many varieties in market economies. The idea that institutional complementarities would preclude change is clearly not consistent with the empirical evidence, but it helps in explaining why some changes are logically followed by others. If the public expects CEOs to take on more responsibilities, then the logical consequence will be more collaboration between CEOs and between employers and employees, more government coordination, and another role for CEOs.

Capitalism and the CEOs of large companies have been under fire since the start of the twenty-first century. It is too early to decide whether the present societal pressure for a more sustainable capitalism and a more "responsible" CEO will signify a new shift in the role of the CEO, but this paper makes clear that over time the role has not been static. That means there is room for future change, or should we say room for "improvement"? 
Bibliography of Works Cited

\section{Books}

Beekenkamp, Gerbert G. President-directeuren, posities en patronen. Een studie naar de rekrutering van de leiders van de 250 grootste ondernemingen in Nederland. Bezorgd door J. Dronkers \& T. Dronkers-Vlaming. Amsterdam: Aksant, 2002.

Crouch, Colin. Capitalist Diversity and Change: Recombinant Governance and Institutional Entrepreneurs. Oxford: Oxford University Press, 2005.

David, Thomas, and Gerarda Westerhuis, eds. The Power of Corporate Networks: A Comparative and Historical Perspective. London: Routledge, 2014.

Dronkers, Jacob, and Frans N. Stokman. Nederlandse elites in beeld. Recrutering, samenhang en verandering. Deventer, Neth.: Van Loghum Slaterus, 1984.

Drucker, Peter F. The Practice of Management. London: Pan Books, 1968.

Empel, Frank van, and John Jansen van Galen. Captains of Industry. Topmanagers van Shell, Philips, Akzo, Unilever, Wessanen, Van Leer, Volvo, Gamma Holding, Fri-d'Or, Cebeco, en HBG over de economie van het ondernemen. Amsterdam: Uitgeverij De Viergang, 1985.

Fligstein, Neil. The Architecture of Markets: An Economic Sociology of TwentyFirst-Century Capitalist Societies. Princeton: Princeton University Press, 2001.

- The Transformation of Corporate Control. Cambridge, MA: Harvard University Press, 1990.

Hall, Peter A., and David Soskice, eds. Varieties of Capitalism: The Institutional Foundations of Comparative Advantage. Oxford: Oxford University Press, 2001.

Hancké, Bob, Martin Rhodes, and Mark Thatcher, eds. Beyond Varieties of Capitalism: Conflict, Contradictions, and Complementarities in the European Economy. Oxford: Oxford University Press, 2007.

Heemskerk, Eelke M. Decline of the Corporate Community: Network Dynamics of the Dutch Business Elite. Amsterdam: Amsterdam University Press, 2007.

Horringa, Dirk. Leiderschap en organisatie in de Nederlandse onderneming. Assen, Neth.: van Gorcum, 1959.

Icke, B. L., Robert Jan Mokken, and Huibert Schijf. Technologie \& Management. Bestuursstructuren in industriële ondernemingen. Utrecht/Amsterdam: Technologiestichting STW/Het Spinhuis, 1997.

Khurana, Rakesh. Searching for a Corporate Savior: The Irrational Quest for Charismatic CEOs. Princeton: Princeton University Press, 2002.

Lawrence, Peter. Management in the Netherlands. Oxford: Clarendon Press, 1991.

Morgan, Glenn, Richard Whitley, and Eli Moen, eds. Changing Capitalisms? Internationalization, Institutional Change, and Systems of Economic Organization. Oxford: Oxford University Press, 2005.

Reich, Robert B. Supercapitalism: The Transformation of Business, Democracy, and Everyday Life. New York: Alfred A. Knopf, 2007.

Shiller, Robert J. Finance and the Good Society. Princeton: Princeton University Press, 2012. 
Sluyterman, Keetie. Dutch Enterprise in the Twentieth Century: Business Strategies in a Small Open Economy. London: Routledge, 2005.

Sluyterman, Keetie. Keeping Competitive in Turbulent Markets, 1973-2007. Vol. 3, A History of Royal Dutch Shell. Oxford: Oxford University Press, 2007.

- , ed. Varieties of Capitalism and Business History: The Dutch Case. New York: Routledge, 2015.

Sluyterman, Keetie, and Ben Wubs. Over grenzen. Multinationals en de Nederlandse markteconomie. Amsterdam: Boom, 2009.

Smit, Jeroen. Het drama Ahold. Amsterdam: Balans, 2004.

- Het grote gevecht \& het eenzame gelijk van Paul Polman. Amsterdam: Prometheus, 2019.

Touwen, Jeroen. Coordination in Transition: The Netherlands and the World Economy, 1950-2010. Leiden, Neth.: Brill, 2014.

Verbraak, Coen. Kijken in de ziel van topondernemers. Amsterdam: Uitgeverij Thomas Rap, 2014.

Vet, Anton C. W. van der. Per slot van rekening: A. C. W. van der Vet interviewt zes ondernemers over hun levenswerk. Den Haag/Antwerpen: Uitgeversmaatschappij Succes, 1969.

Vinke, Pieter. De maatschappelijke plaats en herkomst der directeuren en commissarissen van de open en daarmede vergelijkbare besloten naamloze vennootschappen. Leiden, Neth.: H. E. Stenfert Kroese, 1961.

Westerhuis, Gerarda, and Abe de Jong. Over geld en macht. Financiering en corporate governance van het Nederlandse bedrijfsleven. Amsterdam: Boom, 2015.

Whitley, Richard. Divergent Capitalisms: The Social Structuring and Change of Business Systems. Oxford: Oxford University Press, 2000.

\section{Articles and Chapters in Books}

Bourdieu, Pierre, and Monique de Saint Martin. "Le Patronat." Actes de la recherche en sciences sociales, no. 20/21 (1978), 3-82.

Bühlmann, Felix, Thomas David, and André Mach. "The Swiss Business Elite (1980-200): How the Changing Composition of the Elite Explains the Decline of the Swiss Company Network." Economy and Society 41, no. 2 (2012): 199-226.

Chatterjee, Arijit, and Donald C. Hambrick. "It's All about Me: The Narcissistic Chief Executive Officers and Their Effects on Company Strategy and Performance.” Administrative Science Quarterly 52, no. 3 (2007): 351-386.

Dronkers, Jacob "Mythen over Elites. De rol van het onderwijs bij de recrutering van directeuren van grote bedrijven." Amsterdam Sociologisch Tijdschrift 9, no. 4 (1983): 606-646.

Ellersgaard, Christophe, Anton Grau Larsen, and Martin D. Munk. "A Very Economic Elite: The Case of the Danish Top CEOs.” Sociology 47, no. 6 (2012): 1051-1071.

Fioole, Wouter, Hugo van Driel, and Peter van Baalen. "Europeanisation and Americanisation: Converging Backgrounds of German and Dutch Top Managers, 1990-2005.” In The European Enterprise. Historical Investigation 
into a Future Species, edited by H. G. Schröter, 155-167. Berlin: Springer, 2008.

Freye, Saskia. "Germany's New Top Managers? The Corporate Elite in Flux, 1960-2005." Max-Planck-Institut für Gesellschaftsforschung (MPIfG) Discussion Paper, no. 10/10, 2010.

Friedman, Walter, and Richard Tedlow. "Statistical Portraits of American Business Elites: A Review Essay.” Business History 45, no. 4 (2003): 89-113.

Ginalski, Stephanie. "Who Runs the Firm? A Long-Term Analysis of Gender Inequality on Swiss Corporate Boards.” Enterprise \& Society published online, 2 March 2020, 1-29.

Hartman, Michael. "Class-Specific Habitus and the Social Reproduction of the Business Elite in Germany and France." The Sociological Review 48, no. 2 (2000): 241-261.

Heemskerk, Eelke Michiel, and Meindert Fennema. "Women on Board: Female Board Membership as a Form of Elite Democratization." Enterprise and Society 15, no. 2 (2014): 252-284.

Hjelbrekke, Johs, Brigitte Le Roux, Olav Korsnes, Frédéric Lebaron, Lennart Rosenlund, and Henry Rouanetet. "The Norwegian Field of Power Anno 2000." European Societies 9, no. 2 (2007): 245-273.

Jong, Abe de, Ailsa Roell, and Gerarda Westerhuis. "The Evolving Role of Shareholders in Dutch Corporate Governance.” In Varieties of Capitalism and Business History: The Dutch Case, edited by Keetie Sluyterman, 50-77. London: Routledge, 2015.

Jong, Abe de, Douglas de Jong, Gerard M. H. Mertens, and Peter G. J. Roosenboom. "Royal Ahold: The Role of Corporate Governance." In A Handbook of Corporate Governance and Social Responsibility, edited by G. Aras and D. Crowther, 595-619. Burlington, UK: Gower Publishing, 2010.

Jong, Abe de, Philip Fliers, and Gerarda Westerhuis. "Exceptional Big Linkers: Dutch Evidence from the 20th Century." Business History published online, 25 October 2019: 1-31.

Kaplan, Steven N. “Are U.S. CEOs Overpaid?” Academy of Management Perspectives 22, no. 2 (May 2008): 5-20.

Lazonick, William, and Mary O’Sullivan. "Maximizing Shareholder Value: A New Ideology for Corporate Governance." Economy and Society 29, no. 1 (2000): 13-35.

Maclean, Mairi, Charles Harvey, and Robert Chia. "Dominant Corporate Agents and the Power Elite in France and Britain." Organization Studies 31, no. 3 (2010): 327-348.

Mayer, Michael, and Richard Whittington. "Euro-Elites: Top British, French and German Managers in the 1980s and 1990s." European Management Journal 17, no. 4 (1999): 403-408.

Mizruchi, Mark S., and Linroy J. Marshall. "Corporate CEOs, 1890-2015: Titans, Bureaucrats, and Saviors.” Annual Review of Sociology 42, no. 1(2016), 143-163.

Riggio, Ronald E. "Management and Leadership." In Oxford Handbook of Management, edited by Adrian Wilkinson, Steven J. Armstrong, and 
Michael Launsbury, 276-292, Oxford/New York: Oxford University Press, 2017.

Sluyterman, Keetie, and Ben Wubs. "Multinationals as Agents of Change.” In Varieties of Capitalism and Business History: The Dutch Case, edited by Keetie Sluyterman, 156-182. New York: Routledge, 2015.

Stokman, Frans N., Frans W. Wasseur, and Donald Elsas. "The Dutch Network: Types of Interlocks and Network Structure.” In Networks of Corporate Power: A Comparative Analysis of Ten Countries, edited by Frans N. Stokman, Rolf Ziegler, and John Scot, 112-130. Cambridge, UK: Polity Press, 1985.

Veen, Kees van, and Ilse Marsman. "How International Are Executive Boards of European MNCs? Nationality Diversity in 15 European Countries.” European Management Journal 26, no. 3 (2008): 188-198.

Westerhuis, Gerarda. "The Dutch Corporate Network: Considering Its Persistence." In The Power of Corporate Networks: A Comparative and Historical Perspective, edited by Thomas David and Gerarda Westerhuis, 89-107. London: Routledge, 2014.

Newspapers and Magazines

The Economist

Elsevier's Weekblad

Fortune

Harvard Business Review

Management Scope

NRC Handelsblad

Time Magazine (Atlantic edition) 